\title{
Pengenalan Teknologi Sederhana Pengolahan Saus Berbasis Pangan Lokal pada Anggota 'Aisyiyah Kota Semarang
}

\author{
Introduction of Simple Technology of Local Food-Based Sauce Processing \\ for Members of Semarang City Aisyiyah
}

\author{
Siti Aminah*1', Wikanastri Hersoelistyorini, Nurrahman \\ Universitas Muhammadiyah, Semarang, Indonesia \\ *Penulis Korespondensi \\ 1itiaminah@unimus.ac.id
}

Riwayat Artikel: Dikirim 5 April 2021; Diterima 31 Mei 2021; Diterbitkan 31 Mei 2021

\begin{abstract}
Abstrak
Saus dan saus sambal merupakan salah satu produk pasta yang cukup dikenal dan digemari dimasyarakat. Produk tersebut dapat diolah melalui teknologi sederhana ditingkat rumah tangga. Bahan pangan lokal seperti pepaya, labu kuning, dan labu siam dapat didayagunakan sebagai bahan baku saus. Teknologi tepat guna pengolahan saus dengan bahan lokal belum banyak diketahui oleh masyarakat. Kegiatan ini bertujuan untuk mengenalkan teknologi tepat guna pengolahan saus dan saus sambal dengan bahan baku lokal. Metode pelaksanaan kegiatan melalui pelatihan meliputi ceramah untuk materi teori tentang keamanan pangan, bahan tambahan pangan dan pengemasan. Sedang pengenalan teknologi tepat guna dilakukan dengan praktikum. Untuk pelaksanaan praktikum, peserta dibagi dalam kelompok (5 orang/kelompok). Target sasaran kegiatan ini adalah anggota 'Aisyiyah Kota Semarang sebanyak 50 orang. Secara umum hasil kegiatan menunjukkan bahwa target peserta terpenuhi sebanyak 50 orang, dan semua mengikuti rangkaian kegiatan hingga akhir. Partisipasi dan keaktifan semua peserta dalam ceramah maupun praktikum menunjukkan bahwa kegiatan pengabdian ini tercapai. Hasil praktikum berupa produk saus dan saus sambal secara umum memiliki karakteristik yang cukup bagus yang dihasilkan. Hal ini menunjukkan bahwa teknologi tepat guna pengolahan saus dan saus sambal dengan diversifikasi bahan pangan lokal dapat dimengerti, dipahami dan diimplementasikan dengan baik oleh seluruh peserta. Kegiatan ini telah dapat memberikan informasi baru kepada peserta di samping proses pengolahan juga pendayagunaan bahan-bahan lokal yang belum diketahui oleh peserta sebelumnya.
\end{abstract}

Kata kunci: pangan lokal, teknologi tepat guna, saus, 'Aisyiyah Semarang

\begin{abstract}
Sauce and chili sauce are pasta product that well-known and popular in the community. These products can be processed through simple technology at the household level. Local food ingredients such as papaya, pumpkin, and chayote can be used as raw material for sauces. Not many people know about the appropriate technology for processing sauces with local ingredients. This activity aims to introduce appropriate technology for processing sauces and chili sauce with local ingredients. The method of implementing activities was through training includes lectures for theoretical material on food safety, food additives and packaging. While the introduction of appropriate technology was carried out by practicum. For carrying out practicum, participants were divided into groups (5 people I group). The target of this activity is 50 members of 'Aisyiyah Semarang City. In general, the results of the activities showed that the target participants were 50 people, and all of them followed a series of activities until the end. The participation and activeness of all participants in lectures and practicum showed that this service activity bas been achieved. The results of the practicum in the form of sauce and chili sauce products generally had fairly good characteristics. This shows that the appropriate technology for processing sauces and chili sauce with diversification of local food ingredients can be understood and implemented properly by all participants. This activity has been able to provide new information to participants in addition to the processing process as well as the utilization of local materials that have not been known to the participants beforehand.
\end{abstract}

Keywords: local food, simple technology, sauce, Aisyiyah, Semarang 


\section{PENDAHULUAN}

Saus adalah salah satu pelengkap yang ditambahkan pada suatu hidangan (kondimen) berbentuk pasta. Ada berbagai produk saus, namun secara umum dimasyarakat dikenal dua jenis saus, yaitu saus tomat dan saus cabe. Saus cabe didefinisikan sebagai olahan saus dari bahan utama cabai (capsicum sp) yang baik, yang diolah dengan penambahan bumbu-bumbu dengan atau tanpa penambahan bumbubumbu dengan atau tanpa penambahan bahan makanan lain dan bahan tambahan pangan yang diizinkan (Badan Standarisasi Nasional, 2006).

Bahan baku saus umumnya adalah tomat, namun demikian beberapa jenis tanaman hortikultura dan umbi-umbian dapat digunakan sebagai bahan baku saus maupun saus sambal. Di antara bahanbahan tersebut adalah: labu siam, wortel, pepaya, pepaya, labu kuning dan umbi rambat (Hilmy et al., 2019; Indrawati et al., 2018; Koswara, 2009; Yahdiyani Ikhsani et al., 2015). Indonesia, khususnya Jawa Tengah memiliki potensi produksi tanaman hortikultura dan umbi-umbian cukup besar. Data dari Badan Pusat Statistik menunjukkan produksi beberapa tanaman hortikultura tahun 2019 adalah sebagai berikut: cabai rawit 148.750 ton; cabai besar 42. 698 ton, labu siam 1.609 ton, tomat 817097 , pepaya: 117409 ton (BPS, 2020), dan ubi jalar produksi pada tahun 2018 sebanyak $152.056 \mathrm{kw} / \mathrm{ha}$, luas panen 5.430 (BPS, 2019). Besarnya hasil produksi tersebut dapat dikembangkan menjadi produk-produk olahan seperti saus maupun saus sambal.

Produksi saus dan saus sambal semakin pesat, karena kebutuhan masyarakat semakin tinggi. Pusat Data dan Informasi Pertanian (2018) melaporkan bahwa rata-rata konsumsi saus atau saus sambal sebanyak $140 \mathrm{ml} /$ minggu. Oleh karena itu saat ini produksi saus semakin berkembang. Namun pada satu sisi keamanan produk saus juga harus mendapat perhatian, baik dari aspek higiene sanitasi maupun bahan tambahan yang berbahaya.

Saus dan saus sambal dapat diproduksi ditingkat rumah tangga. Teknologi pengolahan saus sangat sederhana, alat-alat yang dip 'erlukan umumnya sudah tersedia di setiap rumah tangga. Oleh karena potensi ketersediaan bahan baku dan proses pengolahan sederhana, maka teknologi tepat guna pengolahan saus perlu dikenalkan kepada masyarakat.

'Aisyiyah adalah organisasi gerakan perempuan yang bersifat sosial keagamaan bergerak Saus dan saus sambal dipandang sebagai produk potensial untuk dapat diproduksi ditingkat rumah tangga. Permasalahannya adalah masih kurangnya ketrampilan dan pengetahuan anggota 'Aisyiyah dalam aplikasi teknologi sederhana pengolahan saus dan saus sambal. Oleh karena ini perlu dilakukan introduksi teknologi tepat guna pengolahan saus pada anggota 'Aisyiyah di Kota Semarang. Pengabdian ini dilaksanakan melalui kerja sama Majelis Ekonomi Pimpinan Daerah 'Aisyiyah Kota Semarang di semua bidang. Kemandirian perempuan dalam bidang ekonomi menjadi salah satu program utama di 'Aisyiyah. Kemampuan dan ketrampilan anggota dalam berwirausaha ataupun pengembangan produk pangan lokal yang sehat dan aman, menjadi salah satu tujuan misi gerakan. Majelis Ekonomi 'Aisyiyah bertanggungjawab atas pelaksanaan program pemberdayaan dan kemandirian ekonomi perempuan. Kegiatan ini secara umum bertujuan untuk: mengenalkan dan meningkatkan pengetahuan tentang: keamanan Pangan; Cara Pengolahan Pangan yang Baik, Bahan Tambahan Pangan; mengenalkan teknologi tepat guna pengolahan saus berbasis pangan lokal kepada anggota 'Aisyiyah Kota Semarang. Hasil kegiatan ini diharapkan dapat memberikan bekal pengetahuan dan ketrampilan bagi anggota 'Aisyiyah Kota Semarang dalam merintis, menguatkan dan mengembangkan wirausaha di bidang 
pangan serta memberikan wawasan kepada anggota 'Aisyiyah dalam diversifikasi bahan pangan lokal.

\section{METODE}

Kegiatan pengabdian ini dilakukan dengan beberapa tahap, yaitu:

\section{Persiapan dan Koordinasi}

Kegiatan ini meliputi penyusunan rencana program, perijinan tempat, penyusunan materi, inventarisasi kebutuhan bahan dan alat, serta koordinasi dengan Majelis Ekonomi Pimpinan Daerah 'Aisiyah (PDA) Kota Semarang.

$$
\text { Majelis Ekonomi PDA Kota }
$$

Semarang bertugas untuk :

a. Mensosialisasi, mengoordinir, dan mengundang anggota perwakilan dari Pimpinan Cabang 'Aisyiyah (PCA) maupun anggota Majelis Ekonomi.

b. Melakukan pendataan atau pendaftaran peserta serta membantu secara teknis pelaksanaan kegiatan.

2. Sosialisasi dan Pendaftaran peserta

\section{Pelaksanaan}

Metode pelaksanaan kegiatan dilakukan dengan ceramah dan praktik pembuatan saus dan saus sambal.

Adapun bahan dan alat yang digunakan meliputi:

Bahan : buku panduan teknologi tepat guna pengolahan sederhana bahan pangan lokal; pepaya, labu siam, labu kuning, wortel, tomat, cabai, bahan pembantu: pewarna makanan, $\mathrm{Na}$ metabisulfit, asam sitrat, gula pasir, bumbu dan rempah.

Alat : LCD, laptop, blender, wajan, kompor, baskom, kain saring dan botol kemasan

Materi : 1. Keamanan Pangan

2. Pengemasan dan Pelabelan

3. Bahan Tambahan Pangan

Peserta : anggota 'Aisyiyah Kota Semarang, sebanyak 50 orang (utusan dari setiap Cabang
'Aisyiyah se Kota Semarang: 16 Cabang, dan Anggota Majelis Pimpinan Daerah 'Aisyiyah Kota Semarang)

Tempat : Universitas Muhammadiyah Semarang, Jl. Kedungmundu Raya No.18 Semarang

\section{HASIL DAN PEMBAHASAN}

\section{Gambaran Umum Sasaran}

Target sasaran kegiatan ini adalah anggota 'Aisyiyah Kota Semarang baik utusan Cabang maupun anggota Majelis tingkat Daerah, sebanyak 50 orang. Peserta diutamakan telah memiliki rintisan usaha atau memiliki rencana usaha bidang pangan. Aisyiyah Kota Semarang memiliki 16 Cabang, berada pada tingkat Kecamatan yang disebut dengan Pimpinan Cabang 'Aisyiyah. Agar supaya hasil pelatihan ini dapat merata dan efisien, maka peserta diambil dari perwakilan / utusan setiap PCA sebanyak 2 orang, dan anggota Majelis ditingkat Daerah. Hal ini dimaksudkan agar peserta dari setiap cabang setelah mendapatkan pengenalan teknologi tepat guna pengolahan saus, dapat menyebarluaskan informasi kepada anggota lain di Cabang masing-masing.

Adapun kriteria peserta adalah: diutamakan telah memiliki atau pernah memiliki usaha, atau berencana merintis usaha. Kriteria ini dibuat dengan maksud, para peserta sudah memiliki gambaran usaha, sehingga setelah mendapatkan pengenalan teknologi tepat guna ini diharapkan akan lebih mudah untuk dapat menambah dan mengembangkan usaha atau produksi. Gambaran peserta berdasarkan usahanya disajikan pada Gambar 1.

Jumlah peserta yang mengikuti kegiatan sebagaimana target yang direncanakan sebanyak 50 orang. 
Gambar 1:

Presentasi Peserta Berdasarkan Jenis Usaha

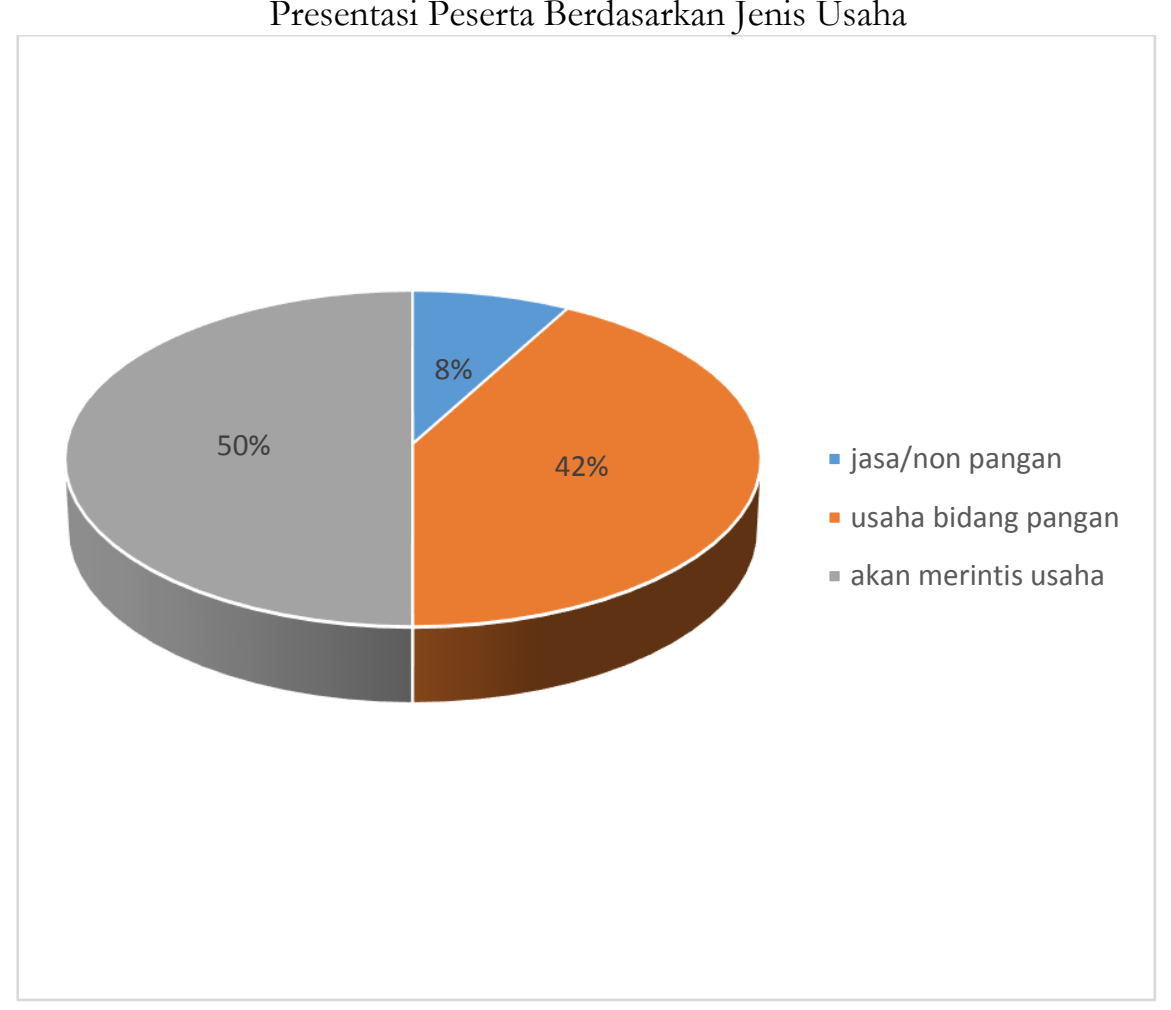

2. Pelaksanaan Kegiatan

a. Materi Teori

Kegiatan dilaksanakan di Kampus Universitas Muhammadiyah Semarang, materi-materi teori diberikan melalui ceramah dan tanya jawab, diberikan di kelas. Materi teori meliputi: 1). Keamanan Pangan; 2). Bahan Tambahan Pangan; 3). Pengemasan dan Pelabelan.

Materi-materi tersebut dipandang sangat penting diberikan untuk meningkatkan pengetahuan kepada masyarakat khususnya pelaku usaha produksi dibidang pangan. Mengingat masih sering dijumpai kasus-kasus yang berkaitan dengan keamanan pangan, baik yang berdampak langsung seperti keracunan maupun yang tidak langsung karena penggunaan bahan-bahan tambahan yang tidak diizinkan maupun melebihi aturan penggunaan. Sebagaimana hasil penelitian Rofieq, Dewangga dan Lubis (2017), melaporkan bahwa $32 \%$ dari 272 sampel makanan jajanan teridentifikasi mengandung bahan tambahan berbahaya (borax, sakarin dan siklamat: melebihi batas penggunaan; rodamin B dan formalin). Aturan penggunaan bahan tambahan pangan sebenarnya sudah diatur dalam Peraturan Bahan Pengawas Obat dan Makanan No. 11 Tahun 2019; peraturan Menteri Kesehatan No. 033 Tahun 2012. Namun demikian sebagian pelaku usaha bidang pangan belum mengimplementasi peraturan-peraturan tersebut.

Selain materi secara langsung diberikan menggunakan Power Point, semua peserta juga mendapatkan print out seluruh materi. Diharapkan peserta dapat mengenali dan memahami materi-materi yang telah diberikan. Namun demikian, diperlukan pengulangan informasi kepada peserta di luar forum kegiatan ini. Oleh karena keterbatasan waktu pelaksanaan, maka sifatnya baru pada tahapan pengenalan. Sehingga tingkat pemahaman materi belum dapat diketahui secara pasti.

\section{b. Materi Praktikum}

Materi teori diberikan dikelas, dan praktikum dilakukan di Laboratorium Pengolahan Pangan. Praktikum dilakukan 
setelah diberikan materi teori. Pelaksanaan praktikum dilakukan dengan membagi peserta dalam kelompok, setiap kelompok terdiri dari 5 orang. Setiap kelompok diberikan 1 paket peralatan, bahan dan buku panduan pengolahan sederhana bahan pangan lokal (sampul buku panduan disajikan pada Gambar 2). Kegiatan praktikum diawali dengan penjelasan mengenai prosedur pengolahan saus dan saus sambal (diagram alir Gambar 4)

Gambar 2:

Sampul Panduan Praktikum

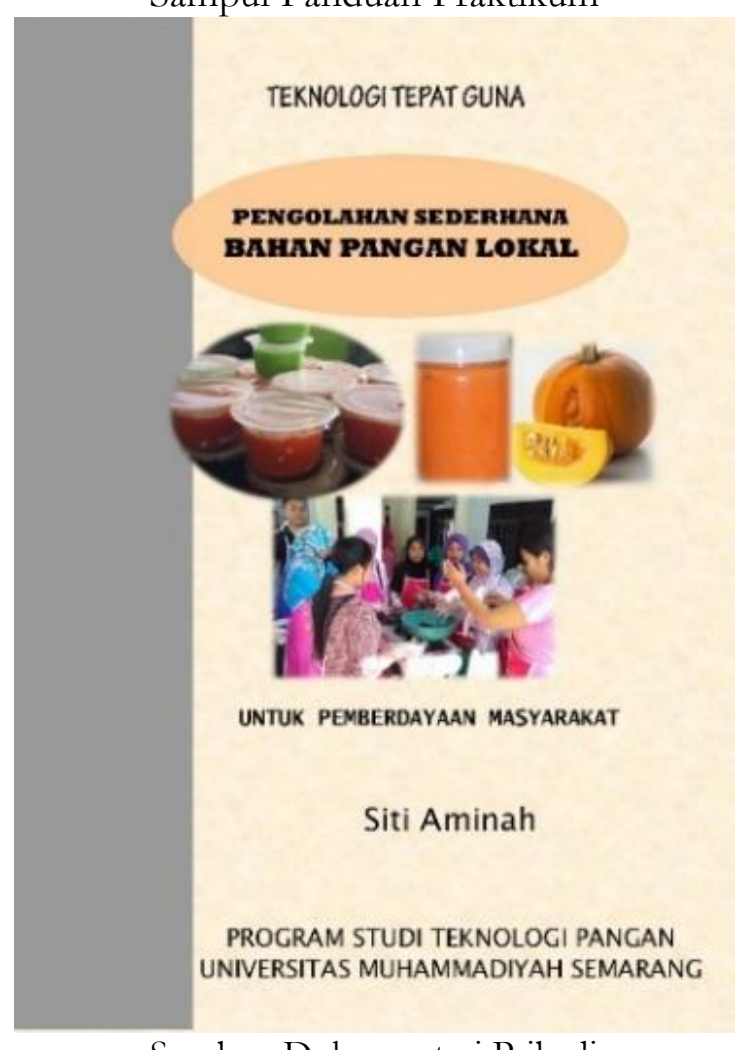

Sumber: Dokumentasi Pribadi

Gambar 3:

Persiapan Praktikum

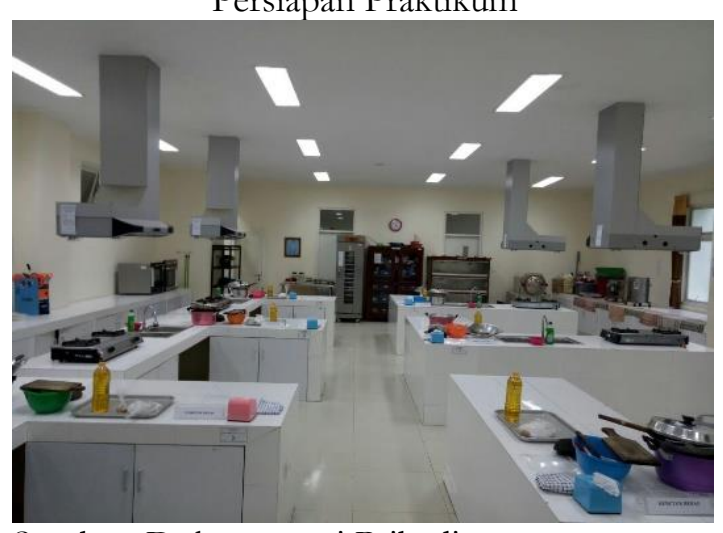

Sumber: Dokumentasi Pribadi
Setiap kelompok praktikum didampingi oleh tim pengabdian (dosen dan mahasiswa program studi Teknologi Pangan Unimus). Setiap kelompok diberikan kesempatan untuk membuat saus atau saus sambal dengan bahan baku yang berbeda. Gambaran kondisi praktikum sebagaimana Gambar 5. 
Gambar 4:

Diagram alir pembuatan saus/saus sambal

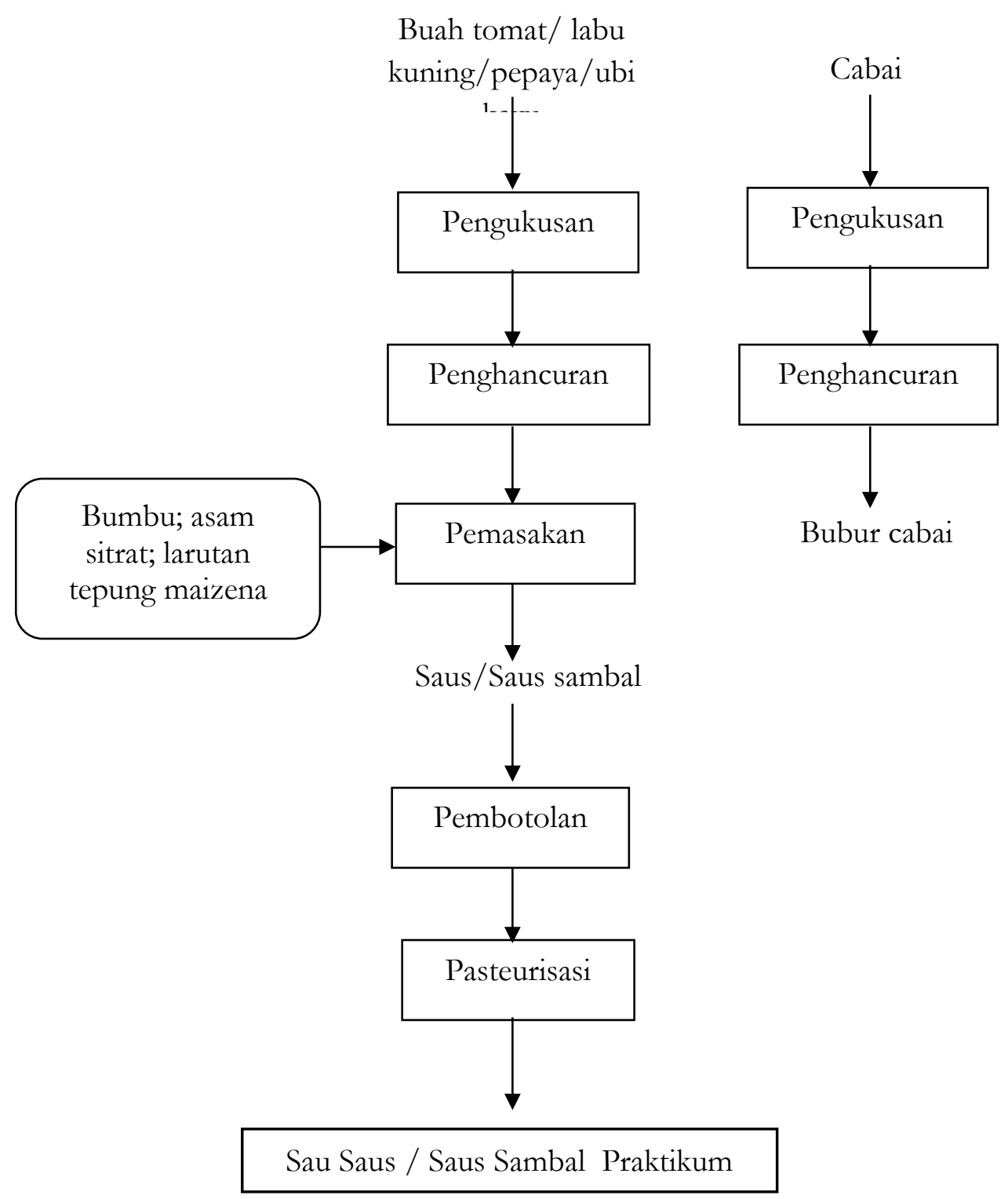

Setelah selesai melakukan praktikum dilakukan evaluasi terhadap karakteristik cita rasa dari produk yang diperoleh oleh setiap kelompok, dan didiskusikan bersama. Secara umum produk hasil praktikum oleh peserta cukup bagus dari komponen konsistensi, rasa, warna maupun aroma. Variasi bahan baku saus dan saus sambal: pepaya, labu siam, labu kuning, wortel, tomat telah dapat diolah dengan baik menjadi saus yang memiliki karakteristik tidak berbeda jauh dengan saus tomat.

Hal tersebut menunjukkan bahwa peserta cukup memahami teknologi sederhana pengolahan saus dan saus sambal yang dikenalkan pada kegiatan ini. Contoh hasil produk praktikum disajikan pada Gambar 6. 
Gambar 5:

Kondisi Praktikum
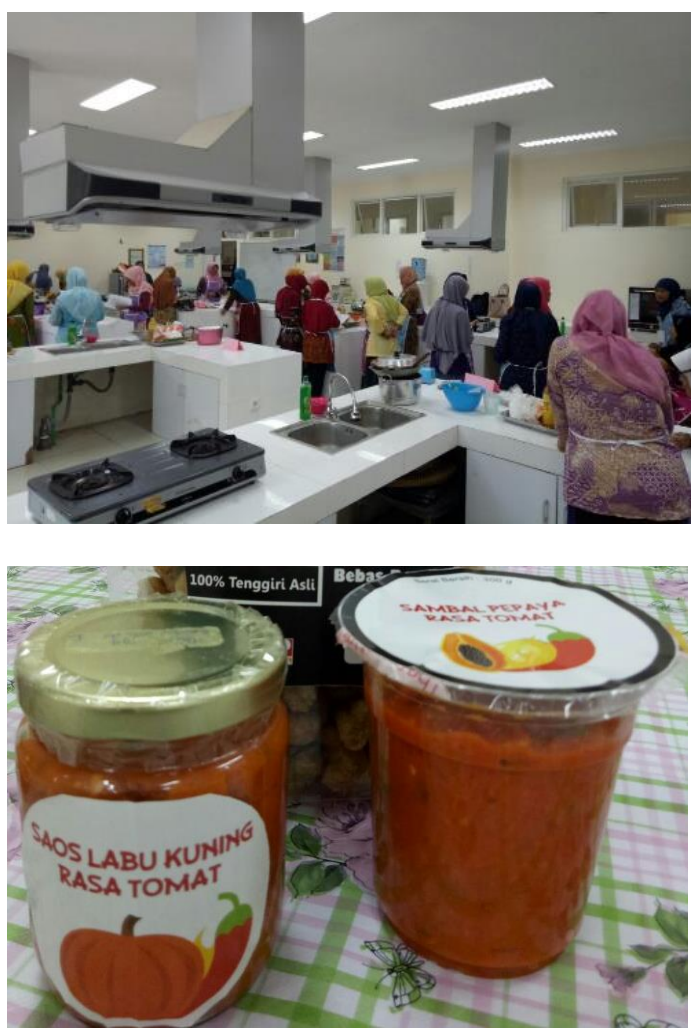

Sumber: Dokumentasi pribadi

Latar belakang peserta sebagian besar adalah ibu rumah tangga yang sudah biasa melakukan pengolahan pangan di dapur masing-masing, nampaknya sangat membantu dalam penerimaan materi pelatihan praktikum ini. Sehingga tidak ada peserta yang merasa kesulitan untuk menerapkan introduksi teknologi sederhana pengolahan saus dan saus sambal.

Diversifikasi bahan baku yang dipraktikkan dalam kegiatan ini juga mampu dimengerti dan dipahami dengan baik oleh semua peserta. Hal tersebut terlihat dari semua proses kegiatan praktikum berjalan dengan baik, dan hasil yang diperoleh cukup bagus. Semua peserta menyatakan belum pernah membuat saus atau saus sambal, baik dari bahan baku tomat, maupun bahan lain sebagaimana yang dipraktikkan pada kegiatan pengabdian ini. Dengan demikian pengolahan saus dan saus sambal ini mampu memberikan informasi kepada masyarakat, khususnya peserta kegiatan terkait dengan teknologi sederhana dan pendayaan gunaan pangan di sekitar kita.

Di samping membuat produk saus dan saus sambal dengan teknologi sederhana, pada praktikum ini juga dikenalkan jenis-jenis pengemas dan cara pengemasan untuk produk saus dan saus sambal.

Pengemasan merupakan bagian yang tidak bisa dipisahkan dalam sebuah produksi. Di samping melindungi produk dari pengaruh lingkungan, memperpanjang masa simpan, juga berperan untuk mempermudah penyimpanan dan distribusi serta memberikan identitas spesifik sebuah produk. (Sucipta et al., 2017). Kemasan yang dikenalkan pada kegiatan ini adalah kemasan kaca dalam bentuk gelas jar dan gelas plastik. Kedua jenis kemasan ini memiliki karakteristik yang berbeda. Kemasan gelas lebih kuat dan tahan terhadap panas.

Peserta pelatihan dalam praktikum sekaligus dapat mengaplikasikan penggunaan bahan tambahan pangan (BTP) sebagaimana yang telah dijelaskan pada materi teori. Bahan tambahan pagan yang diperlukan meliputi: asam sitrat (pengatur keasaman), pewarna makanan dan natrium benzoat (pengawet). Para peserta diberikan kembali penjelasan secara singkat garis besar dan dosis penggunaan bahan makanan tersebut. BTP mempunyai peran penting pada proses pengolahan saus dan saus sambal, di antaranya adalah: peningkatan kualitas sensoris (warna dan rasa) dan memperpanjang masa simpan. Namun demikian masa simpan saus dan saus sambal yang dihasilkan pada kegiatan ini belum bisa diidentifikasi dengan pasti, karena untuk pengamatan daya simpan membutuhkan waktu dan kondisi penyimpanan yang cukup. Sedangkan kegiatan ini dilaksanakan dalam waktu dan singkat dalam rangka mengenalkan teknologi tepat pengolahan saus dan saus sambal berbasis pangan lokal. 


\section{KESIMPULAN}

Kegiatan pengabdian ini dapat dilaksanakan dengan melalui kerja sama dengan Majelis Ekonomi PDA Kota Semarang. Peserta telah mendapatkan informasi tentang keamanan Pangan; Cara Pengolahan Pangan yang Baik, Bahan Tambahan Pangan; serta melakukan aplikasi teknologi pengolahan tepat guna pengolahan saus berbasis pangan lokal serta aplikasi penggunaan bahan tambahan dan teknik pengemasan. Produk hasil praktikum berupa saus dan saus sambal secara sensoris cukup baik.

\section{DAFTAR PUSTAKA}

Badan Standarisasi Nasional. (2006). SNI 01-2976-2006 tentan Saus cabe. http://lib.kemenperin.go.id/neo/deta il.php?id $=226297$

BPS. (2018). Statistik Konsumsi Pangan. http:/ / epublikasi.setjen.pertanian.go.i d/epublikasi/StatistikPertanian/2018 /Konsumsi/Statistik_Konsumsi_Pan gan_Tahun_2018/files/assets/basic$\mathrm{html} /$ page122.html. Page 122 Statistik_Konsumsi_Pangan_Tahun_2 018

BPS. (2019). Luas Panen, Produksi, dan Produktivitas Ubi Jalar Menurut Kabupaten/Kota di Provinsi Jawa Tengah. https://jateng.bps.go.id/statictable/2 019/10/15/1742/luas-panenproduksi-dan-produktivitas-ubi-jalarmenurut-kabupaten-kota-di-provinsijawa-tengah-2018.html

BPS. (2020). Statistik Produk Pepaya. https://www.bps.go.i/indicator/55/6 $1 / 1 /$ produksis-tanaman-sayuran.html Hilmy, H. A., Hintono, A., \& Nurwantoro. (2019). Pengaruh Substitusi Tomat dengan Pepaya terhadap Sifat Kimia dan Kesukaan Saus. Jurnal Teknologi Pangan, 3(1), 86-90. https://ejournal3.undip.ac.id/index.p $\mathrm{hp} /$ tekpangan/article/view/22478
Indrawati, S., Lahming, L., \& Sukainah, A. (2018). Analisis Sifat Fisika Kimia Saus Cabai Fortifikasi Labu Siam dan Labu Kuning. Jurnal Pendidikan Teknologi Pertanian, $\quad 4(0), \quad 113$. https://doi.org/10.26858/jptp.v4i0.6 919

Koswara, S. (2009). Pengolahan Aneka Saus. E-Book Pangan.

Rofieq, A., Dewangga, E. P., \& Lubis, M. H. (2017). Analisis Bahan Tambahan Pangan Berbahaya dalam Jajanan di Lingkungan Sekolah Menengah Atas Propinsi Jawa Timur Indonesia. Research Report, O(0). http://researchreport.umm.ac.id/index.php/research -report/article/view/960

Sucipta, I., Suriasih, K., \& Kencana, P. (2017). Pengemasan Pangan Kajian Pengemasan Yang Aman, Nyaman, Efektif dan Efisien. Udayana University Press.

Yahdiyani Ikhsani, A., Susanto, W. H., Teknologi, J., Pertanian, H., Brawijaya, U., Veteran, M. J., \& Korespondensi, P. (2015). Sifat Fisik Kimia Organoleptik Saus Labu Kuning Pedas-Ikhsani, dkk. In Jurnal Pangan dan Agroindustri (Vol. 3, Issue 2). https://doi.org/10.21776/JPA.V3I2.1 68 